\title{
MONKEY DANCE TRANSFORMATION AND DISPLACEMENT: FROM TRADITIONAL PERFORMANCE TO URBAN EVERYDAYNESS
}

\author{
Anton Sutandio \\ School of Interdisciplinary Arts Ohio University \\ as282609@ohio.edu
}

\begin{abstract}
This research attempts to investigate how the monkey dance, a traditional mobile performance from village to village, transforms and displaces itself into a semi-permanent urban street performance as the effect of modernization and globalization. The research is closely relevant to the theme of the everyday life on the relation between art and the social. Doger monyet (monkey dance) performance has always been regarded as the marginal art/culture. Its place has always been among the mid-lower class of society, thus when it changes its mode and place of performance, questions and curiosity arises. This phenomenon requires a re-examination of the cultural transformation effect to everyday life. This research attempts to answer several issues regarding the phenomena: how the performance negotiates its way to the urban everyday life and its everydayness; how it manages to place itself within the urban space; how it deals with the authority and the urban dwellers, and what its future is going to be like in the new space.
\end{abstract}

Keywords: monkey dance, transformation, displacement, everyday life, place, space

\begin{abstract}
ABSTRAK
Riset ini menginvestigasi pertunjukan doger monyet yang mengalami transformasi dan pergeseran tempat (displacement) pertunjukan, dari satu desa/pinggiran kota ke desa/pinggiran kota lainnya, menuju pusat kota. Modernisasi dan globalisasi adalah dua faktor utama yang menggiring pertunjukan ini ke dalam ruang dan tempat yang baru. Riset ini berhubungan erat dengan tema hidup keseharian (everyday) dan kaitannya dalam hubungan antara seni dan kehidupan sosial. Sebagai bentuk seni, pertunjukan doger monyet ditempatkan sebagai seni/budaya marjinal yang merupakan bagian dari seni hiburan bagi masyarakat kelas bawah. Pertanyaan timbul ketika mode dan ruang seni hiburan ini berubah. Fenomena ini membutuhkan analisa ulang dari efek transformasi budaya terhadap ranah hidup keseharian. Riset ini mencoba untuk menjawab beberapa pertanyaan yang terkait dengan fenomena ini: bagaimana pertunjukan ini melakukan negosiasi untuk masuk ke dalam ranah hidup keseharian kota; bagaimana pertunjukan ini dapat bertahan hidup dalam ruang urban; bagaimana pertunjukan ini menghadapi otoritas kota dan penghuninya; dan seperti apakah masa depan pertunjukan ini di ruang dan tempatnya yang baru.
\end{abstract}

Kata kunci: doger monyet, transformasi, pergeseran tempat, hidup keseharian, tempat, ruang 


\section{INTRODUCTION}

Although this traditional performance has been around for many decades in Indonesia, there are very limited literatures on it. Its basis as a marginal culture and its function as merely entertainment for children might be one of the reasons it goes unnoticed. Thus, the data needed for the research is mainly based on newspaper articles, personal blog sites, and some amateur websites. I find that the available data provided by common people somehow suits the research on the everyday life, as they have firsthand experience and interaction with the performance. To respond to the inquiries, I adopt the method that Joe Austin exercises in his analysis on New York City graffiti/writing art that became an urban crisis in his book Taking The Train. He discusses how graffiti/writing art evolves and attempts to find its place and identity in the hustle bustle of the city whose dwellers are divided between those who accept and reject it. The traditional monkey dance performance virtually undergoes a similar problem when it tries to define and negotiate itself within the urban space.

\section{Bandung: Now and Then}

In "Bandung 1906-1970: Studi Tentang Perkembangan Ekonomi Kota”, Reiza D. Dienaputra argues that the capital of West Java, also known as Paris van Java and Flower City, has experienced drastic transformation in the last century. Since Bandung held the gemeente (municipality) status in 1906, Bandung became politically and economically more significant for the Dutch colonial. Infrastructures were continuously built as the support for a modern city. The basic plan for Bandung during colonization was to make it a leisure gateway for the Westerners. However, the gradual development of Bandung until it became the capital city of West Java brought acceleration to the early plan. The most noticeable impact is from the population growth. In 2007 census, the population is about 2.7 million, compared to 1970 with only 1.1 million people. The city space grows in parallel with the growth of population although in a slower pace. In 1906 the city total area was 900 ha, and in 2005 it developed into 16,730 ha. It grows almost twenty times in a century, and it is still growing. With approximately more than 3 million dwellers in 2010 and crawling space expansion, urban space is rapidly overcrowded and turns into a conflicting and negotiating space between authority, city dwellers and immigrants. Modernization and globalization become the driving force of the urban development. In Sociology of Everyday Life, Andrew J. Weigert argues that the increase of population and urbanization are two important facts about the modern world (7). Modernization in this context refers to the advancement of science and technology which is also part of capitalism impact on big cities. To Henri Lefebvre, it also “... became synonymous with consumer culture” (113). Further, in Globalization in Southeast Asia: Local, National, and Transnational Perspectives, Shinji Yamashita and J.S. Eades states that many cities in Southeast Asia and Indonesia in particular experienced "...massive inflows of goods, money, information and people" (2) as the effect of capitalism and globalization. In Key Concepts in Urban Studies, M. Gottdiener and Leslie Budd define globalization as “...the increased interdependence of the world's economies shown by the circulation of information, money, people and good across national boundaries" (44). Impact of globalization is obvious in Bandung city, for instance it shows through the circulation of international tourists and consequently money, as the result of the opening of direct international flights to and from Bandung in the early $21^{\text {st }}$ century. The growing circulation of people and money attract more people from villages and suburbs to come to Bandung. In Album Bandoeng Tempo Doeloe, Sudarsono Katam and Lulus Abadi argue that Bandung today is overcrowded due to the number of population that grows far beyond the originally projected numbers.

Bandung at present is still a leisure gateway for people from other cities; in its development, it turned into the center of shopping (especially fashion and shoes) and culinary tourism. The latest substantial government project in Bandung was the construction of an anti-earthquake flyover called 'Pasupati' (Pasteur-Surapati) that splits the city in two (image 1). The flyover stretched for about 2.8 
$\mathrm{km}$ from the west to the east part of Bandung, and it becomes a new symbol for the city. The construction intends to overcome the physical distance of space and it consequently shapes the everydayness into a synchronized modernity. The construction took about four years to complete and it started operating in 25 June 2005. The flyover construction also created new spaces underneath (image 2 and 3) that soon turn into a conflicting arena between the everyday life in Bandung and the unfamiliar everyday trying to incorporate itself into the city. In Radical Street Performance, Jan Cohen-Cruz states that, "Space is always controlled by someone and exists somewhere, so is inevitably marked by a particular class or race and not equally accessible to everyone” (2). The urban space in Bandung more or less reflects what Cohen-Cruz says, the opening of new spaces as the result of development always ends up with questions of who has the right to occupy the space and for what purpose. In short, Michel de Certeau in The Practice of Everyday Life states that "...space is a practiced place" (117). Whoever occupies the place and move in it, it becomes space.

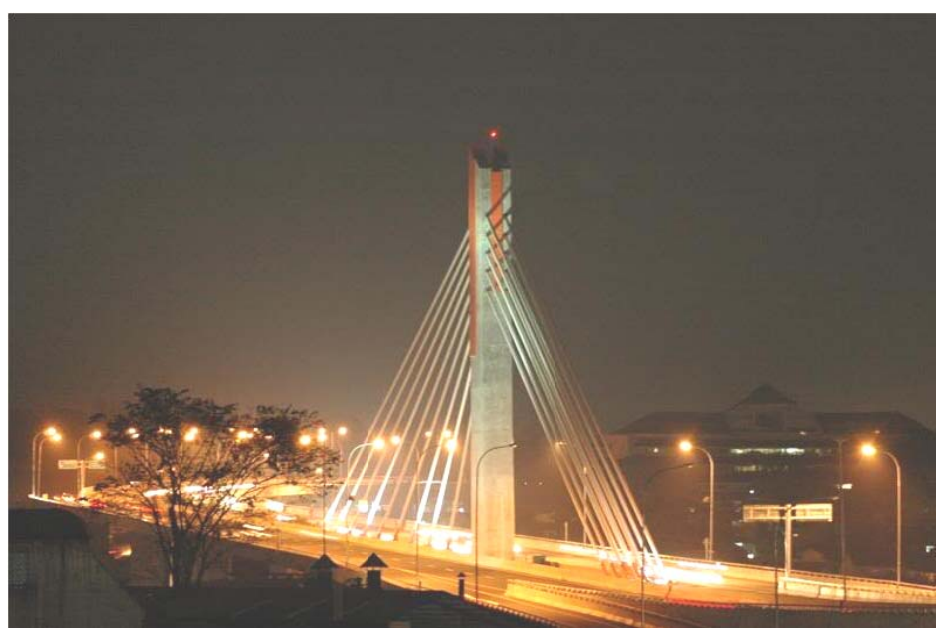

Image 1 : Pasupati flyover, Bandung

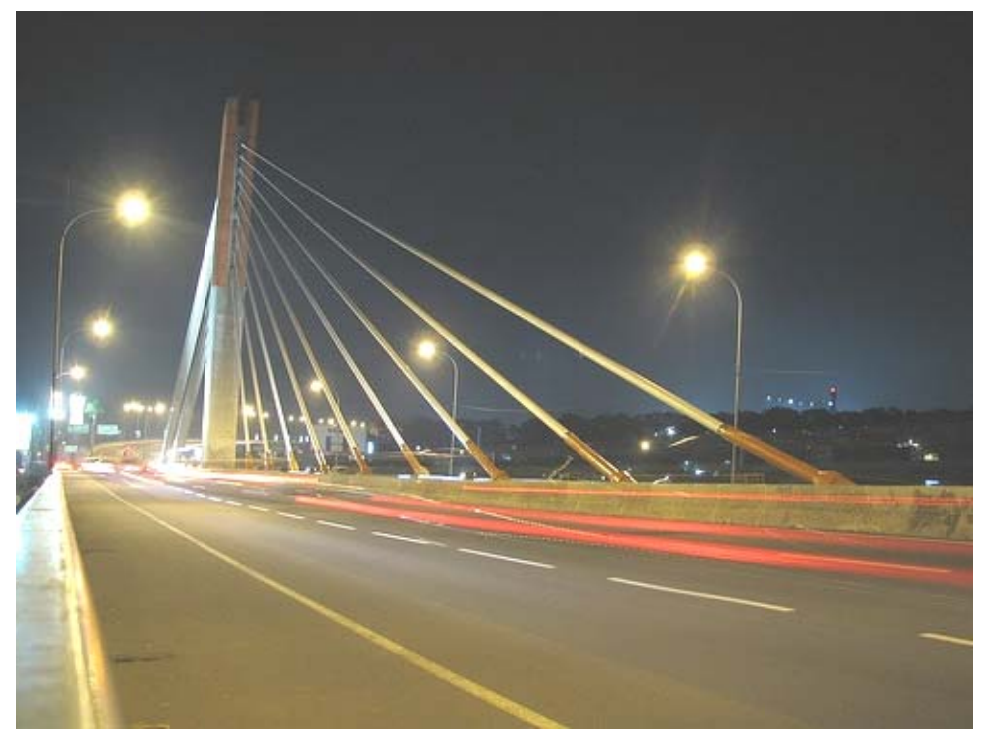

Pasupati Bridge at night 

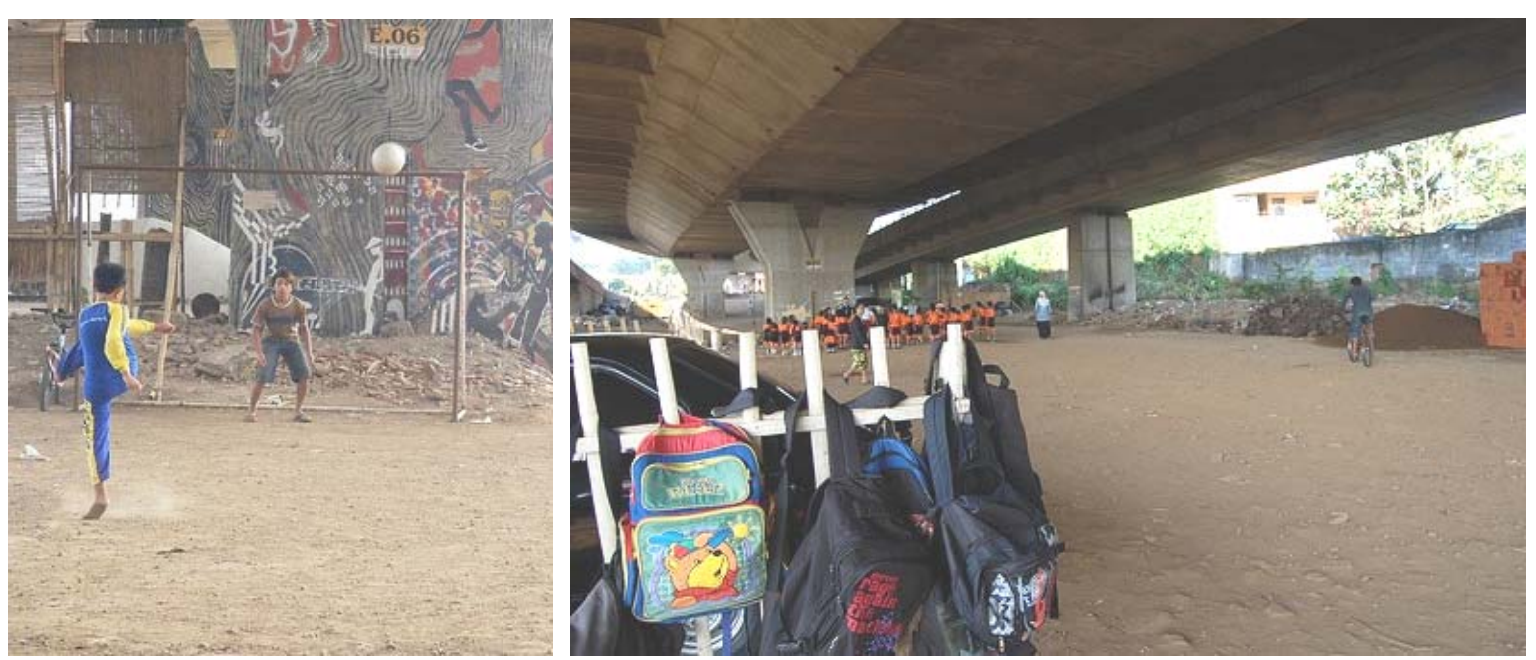

Image 2

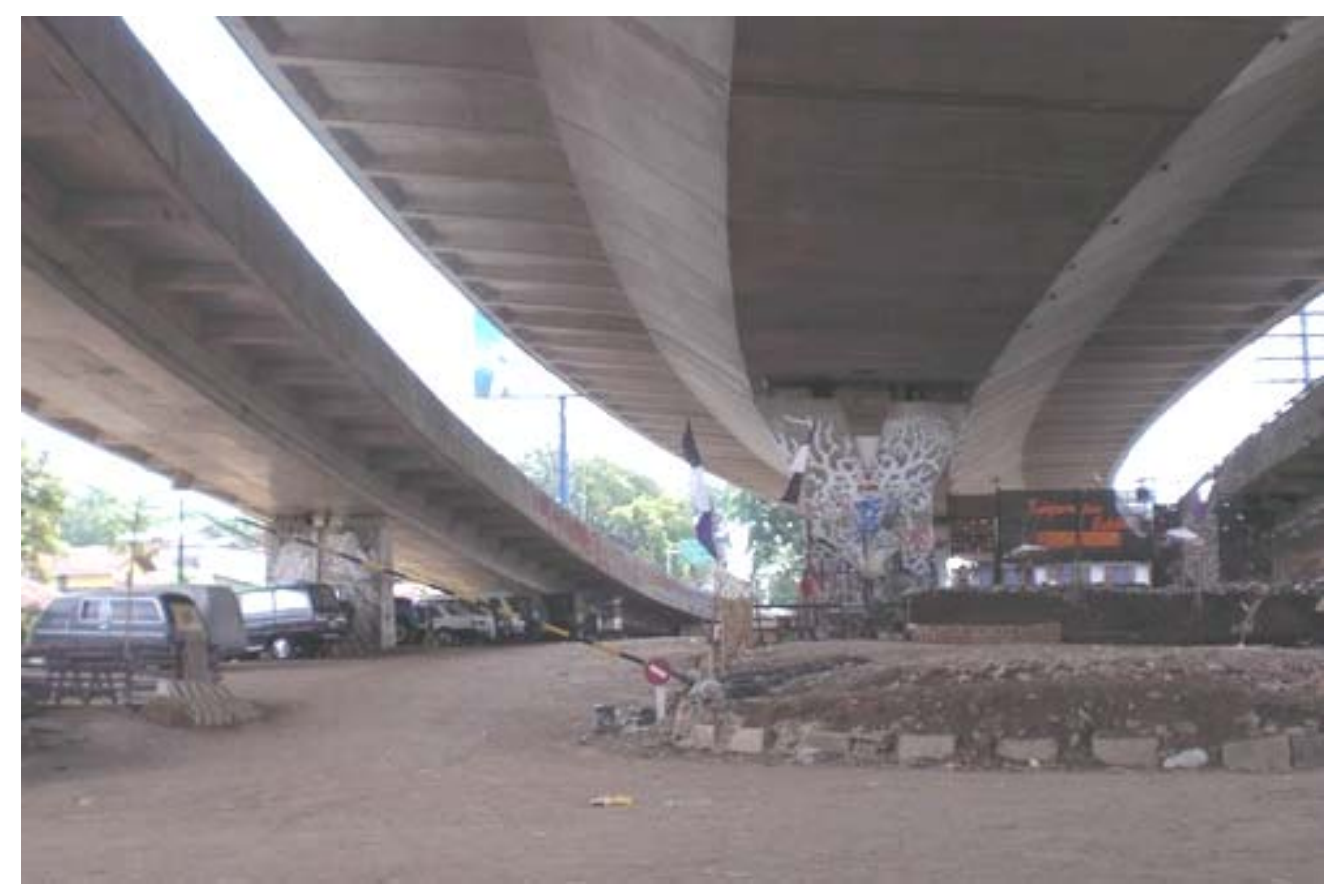

Image 3

The above photos on the space under the flyover show how the place is being practiced and negotiated. The place is originally intended to become a different kind of public space. Unlike other public spaces such as park or town hall, this place is supposed to be sterile from public activities for the sake of the city aesthetic look. However, it has attracted urban public whose "lifespace" is already limited due to the urban development and growing urbanization, thus the place function becomes vague. In the second image on the left, some teenagers make use of the empty spacious place as a soccer arena. In parallel, lack of school space is obvious in the next image where some elementary 
children and their teachers utilize the place to do some exercise. In the third image the place is turned into a parking lot. Graffiti artists also take the advantage of the bare pillar of the flyover as their canvas as seen in the second and third image. The various utilizations of that particular place show how complex the issue of urban space is. In City Publics: The (Dis)enchantments of Urban Encounters, Sophie Watson argues that the $21^{\text {st }}$ century public space is a site of "...multiple connections and interconnections of people..." (12) who come from various background and try to give meaning to the space. This urban space as the result of modernity becomes the heterogeneous and ambivalent landscape of everyday that needs investigating: to the teenagers and the graffiti artists, it might give pleasure and freedom, for the street performers it is probably depressing. It is a never ending negotiation; it is never complete and is always contested.

\section{RESULTS AND DISCUSSION}

\section{Monkey Dance at a Glance}

Cohen-Cruz states that the street performance strives to transport everyday reality into something more ideal as their audience is not theater-goers. "Potentially, street performance creates a bridge between imagined and real actions" (1). As far as the imagination and real actions are concerned, monkey dance performance does just that. What they perform is mundane activities that bring the audience closer to reality in the midst of seemingly unreal moments of their everydayness. In City Publics: The (Dis)enchantments of Urban Encounters, Bim Mason argues that there are several motivations that drive the performers to move to urban space: money, freedom from routine, the spontaneity and the ability to travel (27). From my findings, the major drive for the monkey dance performers is money. Capitalism that leads to the free market has indirectly affected them and forced them to leave the traditional way and at the same time become capitalized.

The origin of monkey dance performance is unknown, but its existence is known in many major areas in Indonesia, proven by the different names it has in different areas throughout Indonesia. The performance is popular in the 80s but then it declines. Despite the bombardment of modern capitalist culture in Indonesia, the performance survives in the marginal areas and attempts to adapt itself in the modern era. The performance involves at least two monkeys, a dog as an option, a monkey trainer, and at least one musician who plays the gamelan. The attraction depends on the skills of the monkey to perform human daily activities such as riding a bicycle, smoking, praying, dancing, saluting or reading newspapers. Based on an interview with the monkey trainer, it could take six months to one year to train one monkey to do the tricks and it pretty much depends on the monkeys themselves. In one day, they can repeat the same performance for twenty times. They train the monkeys by method of action repetition that somehow also reflects the characteristic of everyday modernity: "repetition-of-the-same". It is interesting to observe how the performance has not only affected by modernity, but more than that, it actually performs the concept of modernity. Every elements of the performance, not only the training of the monkeys, is based on repetition. The trainer and the gamelan player are all doing the same thing everyday repetitively.

The monkey dance performance has always been regarded as a marginal culture, and it is probably the reason it goes unnoticed. It circulates around the lower class society, and its main purpose is entertainment for children. Monkey dance performance today has been commercialized and industrialized. There is a special school for monkeys where animal trainers train the monkeys and rent tem. There are also "monkey dance lords" who have many trained monkeys and musical instruments and hire people to perform. To deal with the difficulty of playing gamelan, tape recorder is used as the replacement. Modernity obviously has a great impact on them in their mode and means of performance. 
To perform in the city, they firstly have to negotiate its place in the urban space. As mentioned before, the urban space is a conflicting area between the authority, public and the newcomers. I find that there is no single straightforward answer to explain the reason why eventually the performers manage to occupy certain urban spaces in the city. I am certain though that globalization and modernization play an important role in the negotiation. First, the capitalist culture and modernization drive the performers to enter the urban space. It is a matter of survival for them, both as a culture as well as an occupation. On the other hand, globalization that brings cultural insecurity compels the authority to nurture any kind of traditional culture. The flow of knowledge and information from foreign countries keeps pushing the local culture aside. In Shelter, the Family, and the Environment, Nathaniel Von Einsiedel argues that local authority has to give “... support to indigenous and national cultures-to let them flourish alongside foreign ones" (26). To the authority, globalization and modernization bring competition among cities in Indonesia in many domains: business, tourism, education. Bandung attempts to establish itself as a cultural city, a city that embraces and nurtures traditional culture. Thus, the condition brings win-win solution for them. However, I notice that their placement in specific urban spaces reveals the authority's strategy to localize as well as marginalize them, make them easier to be controlled and supervised. Mason argues that when it comes to street performers, the authority is somewhat distrustful toward them, fearing of their dangerous potential as people who live outside the established society with their own rules (16). This prejudice puts the street performers in an insecure position where the authority can any time remove them from the urban space. Politically, by letting them perform continuously, the authority desires to form public opinion which in time expectantly results in concensus about the performance. Yamashita argues that “... there is no culture without place. Culture has to be localized" (5). This battle of claiming a particular culture as one's local culture is not an uncommon thing that happens in Indonesia lately. The rise of globalization causes local values to be a rarity that needs maintenance and nurturing. As mentioned before, the origin of monkey dance performance is unknown, so the monkey dance performance itself is still pretty much free of any local claim. I argue that this could be the leverage for the performers to perform in the urban space.

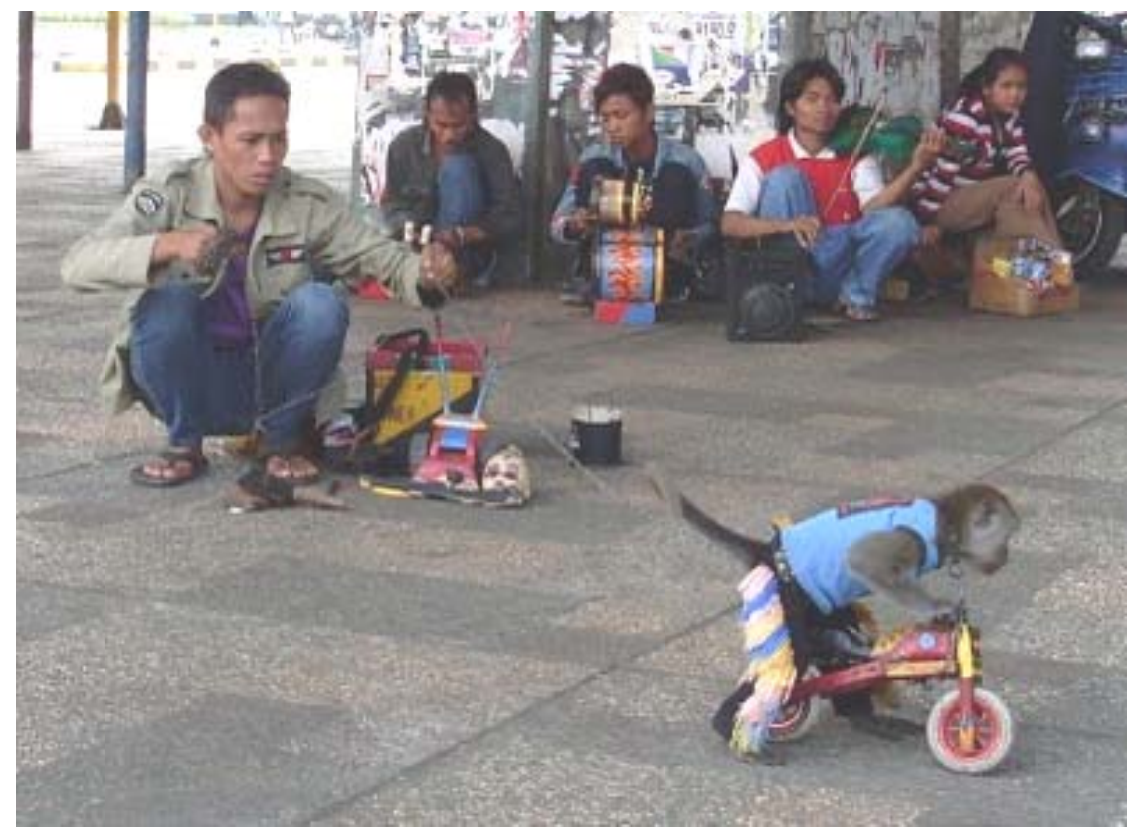

Image 4: Doger monyet performance under the flyover 
In the research of everyday life, the question of whose everyday is the first to answer. In this context, I find at least there are two everyday lives involved: the monkey dance performers and the urban commuters/dwellers. Before the transformation and displacement, they both share different space, but now there are certain strategic spots where the two encounter each other. Once the monkey dance performance leaves its traditional mode of performing, it directly occupies a strategic place in the urban space: street junctions. Cohen-Cruz states that, "The usual rhetoric of street performance configures the street as the gateway to the masses" (2). Driven by economic needs, the performance requires continuous audience, and street junctions are the best option for the performers. In a busy urban street, street junctions are the spots where people are accumulated and where they have to stop for a moment. Street junctions are other inevitable results of city development, where lines of cars and motorcycles have to wait in turn to cross them. Traffic jam on street junctions has become so common in Bandung that it becomes an inseparable part of the everyday life. Street junctions with their traffic lights create ambivalent meanings to the urban dwellers.

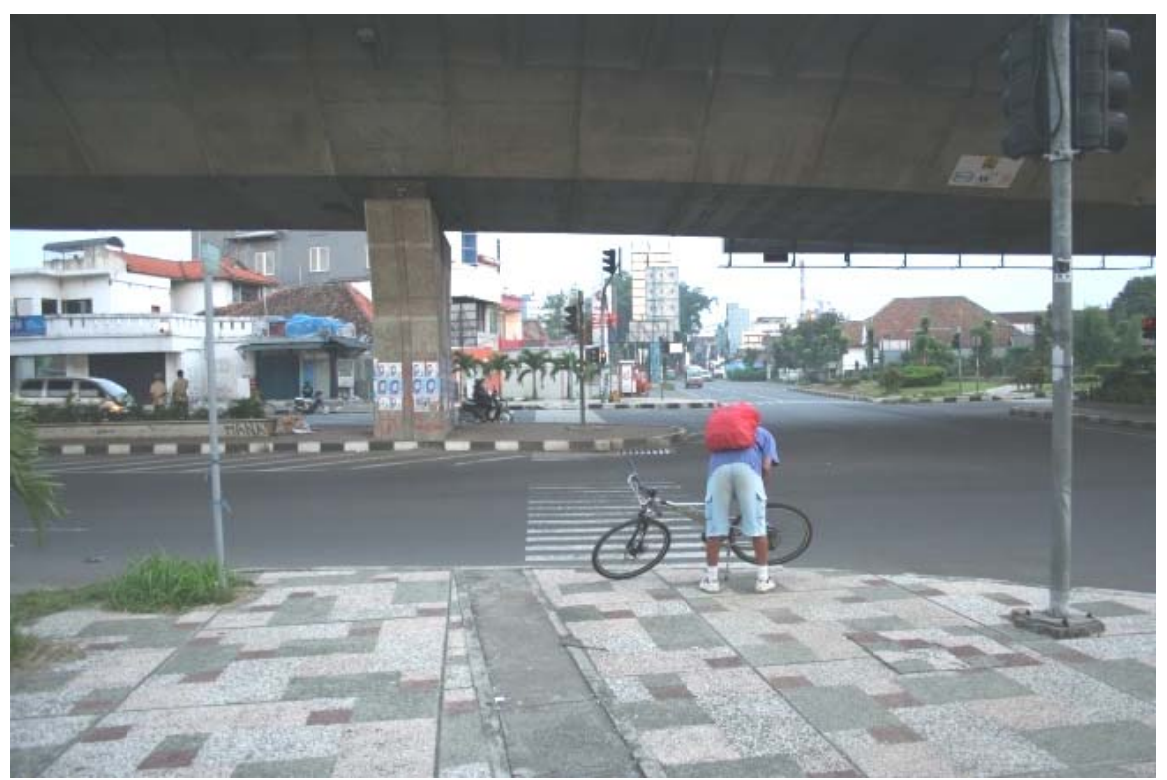

Street Junction between Pasirkaliki and Pasteur Street, Bandung

Traffic lights as the marker of street junctions become one of the "routine daily monitors", "a different temporal experience" that mark each and every day of the urban commuters. In Everyday Life and Cultural Theory: An Introduction, Ben Highmore further argues that, "The everydayness of everyday modernity is a synchronization based on minutes and seconds" (6). Traffic lights perform this synchronization of time daily. They force the urban commuters to obey them. Within modernity, this "monotony" results in the emptying of time. When urban commuters stop at traffic lights, their everyday is momentarily ceased and the ambivalent value of everydayness creeps upon them. Time is temporarily and routinely emptied; it might offer them sanctuary, delight, pain, or boredom, “...time is emptied of any significant markers that would differentiate one moment from the next" (7). Any moment spent at any traffic lights signifies no different moments to the urban commuters. Borrowing Marx's concept on factory work, Highmore states that the moment is “... part of intensification of alienation brought about by modern capitalism' (7). Everyday modernity in a city is signified by 
busyness and work pressure. Bandung commuters, similar to other big cities also experience the alienation. Weigert supports this concept of alienation by stating that urban dwellers become more individualized in the city. Similar to Ben Hamper's statement in Rivethead: Tales from the Assembly Line on the relationship between the assembly line and the stretching out of time, every second and every minute people spent at traffic lights "was a plodding replica of the one that had gone before" (8). Repetition of the time spent waiting for the traffic lights turn green is an unbearable boredom.

When the monkey dance performance enters this "modernity boredom sphere", it inevitably disturbs the urban commuters' everydayness through the exotic, unfamiliar ambience they bring. Both the urban commuters and the performers sense the displacement; to the urban commuters: the sight of monkeys and sound of gamelan in the midst of a busy street that do not blend into its surroundings; to the performers: lines of car, sound of engines, blaring horns, and ignorant audience. The everyday modernity of urban commuters becomes temporarily unrecognizable with the disruption by the unfamiliar attempting to blend into the urban everyday life. Adopting Lefebvre's term, their encounter provides opportunities to create "moments" of vivid sensations, “... a promise of the possibility of everyday life, while at the same time puncturing the continuum of the present'... Moments in this context "... are those instances of intense experience in everyday life that provides an immanent critique of the everyday" (115). The performance somehow draws the audience from their present and brings them to a bizarre everyday. The promise the performance brings might mean the escape from the boredom that works for both parties. To the performers, new space and audience may bring new experience and more income. However, this "escape" does not necessarily signify positive meaning; the sight of the "other" could trigger any possible sensations: pleasure, delight, shocked or even disgust. When two groups of people encounter each other in a certain place and time, dialogue will follow, and this ongoing dialogue is dynamic and ambivalent. This encounter is what Lefebvre states as the "lived experience" through which people structure their everyday life. The structure itself is dynamic; it may change daily through endless encounters with the familiar as well as the unfamiliar banality of daily life. How people deal with this daily encounter determines the meaning they give to their life and it may or may not prevent them from the tanglement and boredom of everyday modernity. With this in mind, I will return to the concept of boredom that results from the 'emptying of time'. As Highmore states, the debilitating boredom is caused by the repetition of the same action. The future of the monkey dance performance will likely become boredom if they stay the same. Their repetitiveaction-based method of performance mirrors the modernity synchronization of time. Although the gamelan sound and spectacle of monkeys are still unfamiliar to the urban life, gradually they will enter the realm of urban life and incorporated into it. When that happens, then the encounter with the urban commuters will lose its sensations. Their transformation and displacement bring them more audience and income and paradoxically may cost them their uniqueness and identity.

\section{CONCLUSION}

The discussion of everyday life is slippery and difficult to grasp. There is no straightforward answer on what everyday may bring in the future. Everyday is dynamic and made complex by various elements that surround it. Globalization and modernization are two major elements in this research. They become the driving force of the monkey dance performance's transformation and displacement. Modernity has greatly affected the traditional performance both positively and negatively. In the new place, they have to negotiate with the authority on the urban space they occupy. The suspicious approval by the authority only shows that the monkey dance performance is in the midst of conflicting arena between political and economical interest. Street junctions in Bandung become their stage and traffic lights lines become their moments. To the urban commuters, traffic lights become the emptying of time; they have to obey the synchronization of time imposed by the traffic lights. Referring to Highmore's concept on boredom, the encounter of the monkey dance performance with the urban 
commuters at traffic lights bring opportunities for both to find new meaning and sensations in their everyday life. The unfamiliar exotic everyday of the performers collide with the everyday of urban commuters at traffic lights where boredom gives birth to possible "moments". These moments may temporarily bring ambivalent change on the structure of everyday. Due to the ambivalence, the encounter of the two different everyday also may end up in many things, something, or nothing. There is no straightforward way of understanding urban encounters in public space. When nothing happens, boredom meets boredom and results in more boredom. In Cities in the $21^{\text {st }}$ Century: Urban Issues and Challenges, Sharifah Norazizan Rashid states the irony of a city which is supposed to be "socially just, ecologically sustainable, politically participatory, economically productive, and culturally vibrant” (1) seems to always lag behind in achieving all that. There is no single city in the world that has successfully managed that. Watson argues that city as, “.... space of segregation, division, exclusion, threat and boundaries" (1) is ambivalence par excellence. In the modern globalized city, anything can and cannot happen. The traditional monkey dance performance, trying to taste the city and gain benefit from it has involuntarily sucked into the mechanization of city. Max Weber argues that everyday life in the city has become an iron cage and society is the prison. Being ambivalent, he also states his historical axiom that city air makes one free. To the performers, city offers new opportunities and freedom, but the everyday modernization at the same time puts them in a "cage". Globalization and everyday modernization result in what Yamashita calls "hybridization and the localization of culture". Monkey dance performance has definitely changed the moment it enters the urban space. How far they will change the urban everyday modernity or be changed by it is still an open discussion as the process is continuing to this very moment.

\section{REFERENCES}

Austin, Joe. Taking the Train. New York: Columbia UP, 2001. Print.

Blue Sky. "Bandung Pasupati Flyover: 2.5 Km with 300 Meter Cable Stayed Bridge”. Skyscrapercity forums. Issue 12 Spring 12. 28 September 2005. Web. 25 January 2010. $<$ http://www.skyscrapercity.com/showthread.php?t=228637>.

Blue Sky. "Bandung Pasupati Flyover: 2.5 Km with 300 Meter Cable Stayed Bridge

Cohen-Cruz, Jan. (ed.). Radical Street Performance: An International Anthology. London: Routledge, 1998. Print.

Colombijn, Freek et.al. (eds.). Kota Lama Kota Baru: Sejarah Kota-kota di Indonesia. Jogjakarta: Penerbit Ombak, 2005. Print.

D. Dienaputra, Reiza. "Bandung 1906-1970: Studi Tentang Perkembangan Ekonomi Kota”. Kota Lama Kota Baru: Sejarah Kota-kota di Indonesia. Freek Colombijn, et.al. (eds.). Jogjakarta: Penerbit Ombak, 2005. 188-210. Print.

De Certeau, Michel. The Practice of Everyday Life. Steven F. Rendall (transl.). Berkeley: UC Press, 1984. Print.

D.S. Katong. “Jembatan Pasupati Bandung”. Flickr Yahoo. 29 October 2008. Web. 27 February 2010. <flickr.com/photos/36041869@N03/3330940636>.

Gottdiener, M. and Leslie Budd. Key Concepts in Urban Studies. London: Sage Publications, 2005. Print. 
Hamper, Ben. Rivethead: Tales from the Assembly Line. Warner Books: New York, 1991. Print.

Highmore, Ben. Everyday Life and Cultural Theory: An Introduction. London: Routledge, 2002. Print.

Highmore, Ben (ed.). The Everyday Life Reader. London: Routledge, 2002. Print.

Katam, Sudarsono and Lulus Abadi. Album Bandoeng Tempo Doeloe. Bandung: Polar, 2006. Print.

Mason, Bim. Street Theatre and Other Outdoor Performance. London: Routledge, 1992. Print.

Rahardjo, Budi. “Doger Monyet”. Padepokan Budi Rahardjo. 31 May 2008. Web. 26 January 2010. < http://rahard.wordpress.com/2008/05/31/doger-monyet/>.

Rashid, Sharifah Norazizan Syed Abd., et.al. (eds.). Cities in the $21^{\text {st }}$ Century: Urban Issues and Challenges. Selangor: UPM Press, 2002. Print.

Rifu. “bandung-jakarta...dengan sepeda lipat!!!” Apapun Lah. Wordpress.com. 31 January 2009. Web. 27 February 2010. < rifu.files.wordpress.com/2009/01/img_0743.jpg>.

Von Einsiedel, Nathaniel. Shelter, the Family, and the Environment. Urban Management Programme, Regional Office for Asia and the Pacific: Kuala Lumpur (?), 1994. Print.

Watson, Sophie. City Publics: The (Dis)enchantments of Urban Encounters. Abingdon: Routledge, 2006. Print.

Weigert, Andrew J. Sociology of Everyday Life. New York: Longman Inc., 1981. Print.

Yamashita, Shinji and J.S. Eades. (eds.). Globalization in Southeast Asia: Local, National, and Transnational Perspectives. New York: Berghahn Books, 2003. Print. 